\title{
PENINGKATAN KEMAMPUAN BAHASA INGGRIS KELOMPOK WANITA TANI (KWT) DI SUKARAJA SUKABUMI
}

\author{
Lusi Susilawati $^{*}$, Siska Hestiana ${ }^{2}$ \\ Program Studi Sastra Inggris Universitas Muhammadiyah Sukabumi \\ Jl. R Syamsuddin, S. H. No. 50 Sukabumi Jawa Barat \\ Penulis Korespodensi : $\underline{\text { lusi@ummi.ac.id/ siskahestiana82@gmail.com }}$
}

\begin{abstract}
Abstrak
Di Sukabumi terdapat beberapa kelompok wanita tani (KWT) yang memiliki potensi untuk meningkatkan hasil produksinya. Salah satu KWT tersebut adalah KWT yang terdapat di wilayah Desa Sukaraja, yaitu kelompok pengolah dan pemasar (POKLAHSAR) Saluyu. Kelompok ini mempunyai keinginan untuk selalu berkembang, oleh karenanya pembinaan perlu dilakukan terhadap KWT tersebut. Hal ini dilakukan karena diharapkan hasil produksinya dapat dipasarkan tidak hanya untuk konsumen lokal namun juga dapat dipasarkan kepada konsumen asing. Tujuan dan target tersebut tentu saja dapat dicapai dengan sebuah metode. Metode yang dimaksud berupa pelatihan bahasa Inggris. Pelatihan tersebut dilaksanakan dalam beberapa tahap yang diawali dengan sosialisasi, pemilihan peserta, pembuatan modul, pelatihan, monitoring dan evaluasi, dan penyusunan laporan. Hasil dari kegiatan pelatihan ini adalah meningkatnya pengetahuan anggota KWT Poklahsar Saluyu terutama pengetahuan mengenai istilah-istilah yang berhubungan dengan pengolahan ikan dalam bahasa Inggris dan dapat melakukan percakapan sederhana dengan menggunakan bahasa Inggris yang dibuktikan dengan sertifikat
\end{abstract}

Kata kunci : Kemampuan Bahasa Inggris, Kelompok Wanita Tani

\section{Pendahuluan}

Pada umumnya petani dapat ditemui di pedesaan dan bekerja di sawah untuk menggarap sawah, namun ternyata petani juga dapat ditemui di wilayah perkotaan, seperti halnya para petani yang berada di Desa Sukaraja Kabupaten Sukabumi. Meskipun secara geografis berada di wilayah kabupaten namun letaknya tidak jauh dari wilayah perkotaan. Di wilayah tersebut terdapat sebuah kelompok wanita tani (KWT) yang memiliki berbagai usaha yang berhubungan dengan pengolahan ikan. KWT tersebut diberi nama KWT kelompok pengolah dan pemasar (poklahsar) Saluyu. KWT tersebut memiliki sejarah yang unik. Pada awalnya anggota KWT tersebut merupakan para ibu rumah tangga yang mengadakan arisan dan kemudian mendirikan kelompok tani. Saat itu KWT tersebut hanya beranggotakan 10 (sepuluh) anggota, namun lambat laun anggotanya bertambah hingga lebih dari seratus anggota. KWT Poklahsar Saluyu memproduksi beberapa makanan olahan ikan dan telah memasarkan produknya ke manamana dengan berbagai olahan makanan yang terbuat dari ikan.

Dari waktu ke waktu produksi olahan ikan KWT Poklahsar Saluyu semakin meningkat dan akhirnya KWT tersebut dilirik oleh pemerintah. Berbagai pelatihan yang berhubungan dengan olahan ikan diberikan pemerintah daerah sehingga dalam berbagai perlombaan meraih juara bahkan menjadi percontohan bagi KWT lain yang berada baik di wilayah kabupaten maupun kota Sukabumi. Dalam berbagai kesempatan kwt tersebut juga pernah diliput oleh televisi nasional.

Kesuksesan yang diraih oleh KWT Poklahsar Saluyu tidak membuat mereka puas. Para anggotanya merasa bahwa masih ada keterampilan lain yang perlu mereka miliki. Suatu keterampilan yang tidak pernah mereka dapatkan dari pelatihan yang selama ini telah mereka peroleh. Keterampilan yang dimaksud adalah keterampilan berkomunikasi dengan menggunakan 
bahasa Inggris. Sebagai dosen yang memiliki latar belakang pendidikan bahasa Inggris, kami merasa perlu untuk memberikan solusi terhadap permasalahan yang mereka miliki yaitu keinginan yang kuat untuk dapat berkomunikasi dengan menggunakan bahasa Inggris. Solusi tersebut adalah dengan memberikan pelatihan bahasa Inggris bagi KWT tersebut.

Seperti dijelaskan sebelumnya bahwa KWT Poklahsar Saluyu memiliki permasalahan kurangnya kemampuan berkomunikasi dengan menggunakan bahasa Inggris. Mereka merasa perlu memiliki kemampuan tersebut sebagai persiapan menghadapi tantangan zaman saat ini, tepatnya dengan adanya MEA dan dengan mulai dibangunnya akses jalan tol menuju BogorCianjur-Sukabumi (Bocimi), terlebih lagi dengan telah dibangunnya beberapa parbrik asing di wilayah Sukabumi. Hal tersebut sudah dipastikan akan berdatangannya turis asing, sehingga persaingan dalam bidang perdagangan pun pastilah sangat ketat. Kebutuhan pelatihan bahasa Inggris, merupakan satu solusi yang dapat menyelesaikan permasalahan mereka dan kegiatan tersebut dilaksanakan dengan target meningkatkan pemahaman dan keterampilan anggota kelompok tani tersebut terhadap beberapa kata, istilah, dan ungkapan yang berhubungan dengan pemasaran produk dalam bahasa Inggris serta mampu berkomunikasi secara fasih dengan menggunakan bahasa Inggris yang dapat dibuktikan dengan sertifikat yang dikeluarkan secara resmi oleh Laboratorium Bahasa Inggris Program Studi Sastra Inggris Universitas Muhammadiyah Sukabumi.

\section{Bahan dan Metode}

Untuk menyelesaikan masalah yang dihadapi oleh KWT Poklahsar Saluyu, maka dilakukan satu metode yang disebut dengan pelatihan bahasa Inggris. Metode pelatihan ini dilakukan dengan beberapa tahap, yaitu: (1) sosialisasi, (2) pemilihan peserta, (3) pembuatan modul, (4) pelatihan, (5) monitoring dan evaluasi, dan (6) penyusunan laporan.
Kegiatan sosialisasi dilakukan dengan tujuan untuk memberikan gambaran kepada para anggota KWT Poklahsar Saluyu tentang program pelatihan bahasa Inggris yang akan dilaksanakan dan manfaat yang dapat mereka peroleh dari kegiatan ini. Mereka diberikan pemahaman apa yang harus dilakukan dalam kegiatan yang akan dilaksanakan dan bagaimana peran mereka dalam kegiatan ini. Kemudian dilakukan kesepakatan bahwa pelatihan dilaksanakan di lokasi KWT Poklahsar Saluyu setiap hari Sabtu jam 10.00 wib selama 90 menit pada setiap pertemaunnya dan sebanyak 16 (enam belas) kali pertemuan.

\section{Hasil dan Pembahasan}

Bahasa Inggris merupakan salah satu bahasa internasional yang saat ini sudah menjadi kebutuhan khususnya dalam dunia perdagangan. Oleh karenanya, bahasa ini harus dikuasai dengan cara mempelajarinya. Namun setiap kebutuhan terhadap bahasa Inggris bagi masing-masing orang sangatlah berbeda, sehingga akan mengakibatkan berbeda juga dalam mempelajarinya. Pernyataan tersebut sejalan dengan pernyataan Edward (2004: 1) bahwa "Different people, of course, use English in different ways. Dari pernyataan tersebut dapat disimpulkan bahwa setiap orang menggunakan bahasa Inggris dengan cara yang berbeda-beda, sebagai contoh bahasa Inggris yang merupakan bahasa kedua digunakan dengan resmi secara lisan di bidang pendidikan ataupun di bidang pemerintahan sedangkan sebagai bahasa asing, bahasa Inggris dipelajari di sekolah-sekolah. Bagi KWT Poklahsar Saluyu bahasa Inggris merupakan bahasa asing yang perlu dipelajari meskipun tidak harus dipelajari melalui pendidikan formal. Pelatihan yang diberikan merupakan salah satu jembatan untuk menguasai bahasa Inggris.

Pembelajaran bahasa Inggris di KWT Poklahsar Saluyu memang berbeda dengan pembelajaran bahasa Inggris pada umumnya. Pembelajaran bahasa Inggris dalam bentuk pelatihan ini selalu diawali dengan menghafal katakata baru baik yang berhubungan dengan kegiatan 
SAKAI SAMBAYAN — Jurnal Pengabdian kepada Masyarakat

sehari-hari maupun yang berhubungan dengan bidang pengolahan ikan. Setiap peserta diwajibkan menghafal 5 (lima) kata baru yang telah dipersiapkan seminggu sebelum pertemuan itu dimulai. Selanjutnya peserta diberikan materi.

Materi pertama yang disampaikan adalah materi perkenalan, yang kemudian pada pertemuan selanjutnya diberikan beberapa materi lain seperti materi tentang cara mengidentifikasi waktu (telling time). Dalam mempelajari Bahasa Inggris, telling time merupakan materi yang sangat dasar yang wajib diketahui (Beare: 2017).

Materi lainnya yang diberikan kepada anggota kelompok wanita tani ini adalah materi tentang bagaimana menanyakan dan memberikan arah dalam bahasa Inggris (Asking and Giving Direction). Materi ini menyampaikan tentang bagaimana menanyakan arah atau lokasi suatu tempat yang sifatnya asing dan juga mengenai bagaimana mengarahkan ke lokasi tersebut. Tempat - tempat yang diarahkan biasanya tempat yang berhubungan dengan pelayanan umum, seperti kantor pos, kantor polisi, bank, dan sebagainya (Arnsten: 2017).

Materi lain yang disampaikan dalam pelatihan adalah mengenai bagaimana menyebutkan angka dalam Bahasa Inggris (telling number).

Setelah para peserta diberikan materi, kemudian dilanjutkan dengan praktek speaking. Praktek speaking dilakukan dengan beberapa metode, diantaranya; (1) monologue, (2) dialogue ataupun (3) discussion. Untuk menghindari kebosanan sesekali dilakukan game dan singing song.

Pada pelatihan ini peserta dilengkapi dengan beberapa alat bantu sebagai penunjang kegiatan seperti modul bahasa Inggris, alat tulis lengkap, kamus bahasa Inggris-Indonesia, dan white board. Khusus materi listening, kami menyediakan mini speaker sebagai pelengkap kegiatan. Berikut adalah beberapa dokumentasi kegiatan:

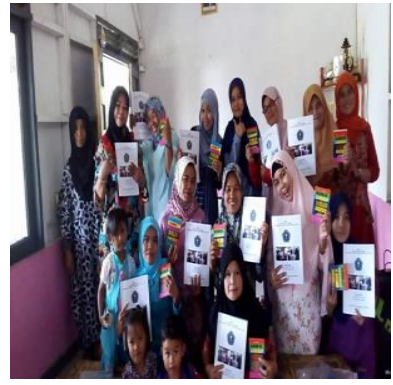

Gambar 1. Pembagian Perlengkapan Pelatihan

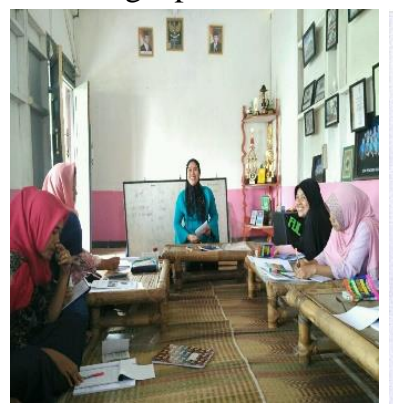

Gambar 3. Pelaksanaan Speaking test

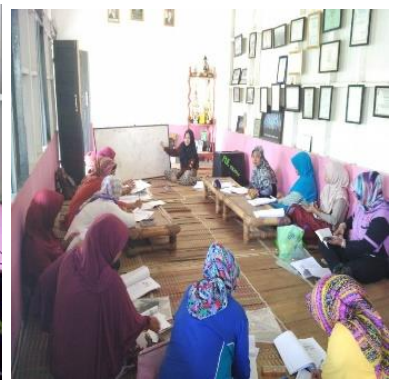

Gambar 2. Kegiatan Pelatihan

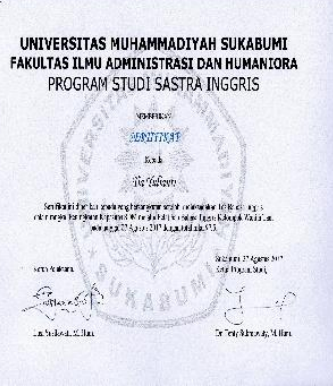

Gambar 4. Sertifikat Pelatihan
Keunggulan dari kegiatan ini khususnya terhadap luaran yang dicapai yaitu mampu berkomunikasi dengan menggunakan bahasa Inggris adalah bahwa anggota KWT Poklahsar Saluyu dapat meningkatkan hasil produksinya jika mampu menawarkan produknya ke warga asing yang kini banyak ditemui di Sukabumi. Adapun kegiatan ini memiliki kelemahan yaitu fokus utama luaran hanyalah speaking, alangkah baiknya fokus luaran merambah ke skill lainnya seperti reading, listening, grammar, dll. Bagaimanapun ketiga skill tadi sangatlah diperlukan terutama masalah grammar. Dykes (2007:192) berpendapat bahwa:

"Due to a number of highly debated factors, some ungrammatical forms of English have become common and in due course may, by default, be regarded as acceptable usage. This is a pity, because, by being grammatically inconsistent, they provide obstacles for those, particularly of nonEnglish speaking origin, who wish to learn correct English. However, this is a phenomenon that has bothered both teachers and students for generations. The language is living - so it happens!" 
SAKAI SAMBAYAN — Jurnal Pengabdian kepada Masyarakat

Dykes menyatakan bahwa banyaknya perdebatan perihal penggunaan bahasa Inggris tanpa menggunakan grammatika yang baik dan benar dianggap sudah biasa tetapi beliau sangat menyayangkan hal tersebut. Meskipun demikian beliau menyadari bahwa itulah fenomena dalam mempelajari bahasa.

Dalam pelatihan ini grammatika bukannya dianggap tidak penting, hanya saja karena latar belakang usia maupun pendidikan dari peserta yang beragam tidak memungkinkan juga untuk mencapai target skill yang lainnya dalam waktu yang singkat. Oleh karenanya, kami berharap dapat melanjutkan kegiatan ini sehingga dapat mencapai target penguasaan semua skill dalam bahasa Inggris.

Kesulitan dalam pelatihan ini kami peroleh adalah masalah waktu. Keputusan hari Sabtu diambil untuk pelaksanaan pelatihan karena para anggota merasa hari Sabtu merupakan waktu yang agak longgar dibanding hari lainnya, namun kenyatannya banyak kegiatan di masyarakat yang juga diadakan di hari Sabtu, seperti perayaan pernikahan dan sunatan di mana beberapa dari anggota biasanya ikut membantu dalam acara tersebut. Selain itu, kelompok tani disibukkan dengan persiapan perlombaan tingkat provinsi dan pameran-pameran sehingga waktu merekn sangat terbagi dan tidak semua anggota dapat mengikuti pertemuan pelatihan dengan lengkap, terlebih ketika menghadapi bulan suci ramadhan. Kegitan terhenti selama satu bulan dan dilanjutkann satu minggu setelah hari raya Idul Fitri.

\section{Kesimpulan}

Kegiatan pelaksanaan pelatihan bahasa Inggris dapat mencapai target yang diharapkan. Beberapa anggota KWT Poklahsar Saluyu dapat melakukan percakapan sederhana dalam bahasa Inggris yang dapat dibuktikan dengan sertifikat yang dikeluarkan oleh Laboratorium Bahasa Inggris Program Studi Bahasa Inggris Universitas Muhammadiyah Sukabumi. Dampak dari kegiatan ini adalah anggota KWT Poklahsar saluyu akan berupaya untuk melakukan komunikasi dengan menggunakan bahasa Inggris. Kami berharap kegiatan pelatihan ini dapat menjadi rekomendasi untuk kegiatan PKM berikutnya.

Kegiatan pelatihan ini juga diharapkan dapat menjadi rekomendasi untuk kegiatan pengabdian ipteks bagi masyarakat (IbM) berikutnya dan diharapkan para petani di seluruh Indonesia dapat melaksanakan kegiatan yang sama dengan berpedoman pada modul yang saat ini menjadi luaran di mana modul tersebut kami modifikasi menjadi sebuah buku ber ISBN dengan judul English for Farmer.

\section{Ucapan Terima Kasih}

Ucapan terimah kasih kami sampaikan sedalam-dalamnya pada semua pihak yang telah membantu terlaksanaya kegiatan pengabdian IbM, khususnya kepada:

1. Kemenristek Dikti atas kepercayaaanya memberikan Hibah IbM.

2. LPPM UMMI yang senantiasa mendukung seluruh kegiatan IbM.

3. Ibu Nur Hasanah, Ketua Poklahsar Saluyu yang telah memberikan ijin untuk melakukan kegiatan IbM.

4. Mahasiswa Sastra Inggris (Alifia, Fatma, dan Aul) yang telah membantu terlaksananya kegiatan IbM.

\section{Daftar Pustaka}

Arnstern, Tara. (2017). How to Teach Direction. http://busyteacher.org/3609-how-to-teachdirections.html <Diakses Tanggal 13 September 2017).

Beare, Kenneth. (2017). Absolute Beginner English Telling Time. https://www.thoughtco.com/beginner-englishtelling-time-1212129. <Diakses tanggal 13 september 2017>.

Dykes, Barbara. (2007). Grammar for Everyone: Practical tools for Learning and Teaching Grammar. Victoria: Acer Press. 
SAKAI SAMBAYAN — Jurnal Pengabdian kepada Masyarakat

Edwards, Viv. (2004). Multilingualism in the EnglishSpeaking World. Australia: Blackwell Publishing. 